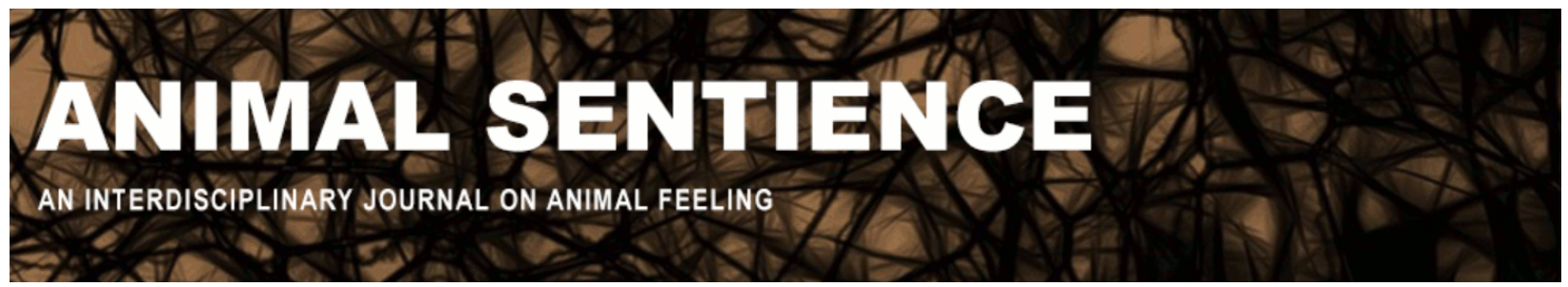

Editorial: Serpell, James A. (2017) In Memory of Patrick Bateson.

DOI: 10.51291/2377-7478.1245

Date of submission: 2017-11-06

Date of acceptance: 2017-11-08

(c) (i)

This article has appeared in the journal Animal

Sentience, a peer-reviewed journal on animal

cognition and feeling. It has been made open access,

free for all, by WellBeing International and deposited

in the WBI Studies Repository. For more information,

please contact

wbisr-info@wellbeingintl.org.

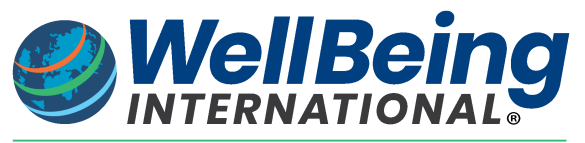

SOLUTIONS FOR PEOPLE, ANIMALS AND ENVIRONMENT 


\section{In Memory of Patrick Bateson}

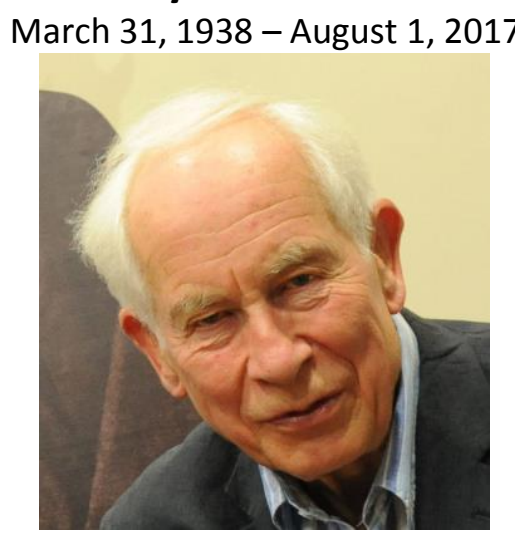

by James $A$. Serpell

On August 1, Sir Patrick Bateson died peacefully at his home in Suffolk, UK, aged 79. I first met Pat Bateson in 1979 when he was the Director of the Sub-department of Animal Behaviour at the University of Cambridge. I was seeking a postdoctoral position to study the relationship between people and their pets: a pretty outlandish idea at the time that Pat met with a sort of bemused but kindly skepticism. While less than encouraging, he nevertheless put me in touch with a scientist at Pedigree Petfoods (now Waltham) who was supposedly interested in supporting research in this area. One thing led to another, and Pat ultimately became my mentor and friend, and set me on the career path I have pursued ever since.

Pat Bateson was a major figure in the field of ethology. He published more than 300 scientific papers and several books mostly on behavioral development, the most recent of which - Development, Behaviour and Evolution - was published earlier this year. His scientific stature, charmingly affable personality, and impeccable Cambridge credentials helped to elevate him through a series of key leadership and administrative roles in science. In 1983, he was elected a Fellow of the Royal Society, and eventually rose to become its Biological Secretary and Vice President in 1998 and 2003, respectively. In 1988 he was elected Provost of King's College Cambridge, a position he held for 15 years, after which he received his Knighthood from the Queen. A year later in 2004, he was elected President of the Zoological Society of London where he continued to preside until 2014.

Pat's scientific research focused initially on the phenomenon of 'imprinting,' a special form of early learning in which young animals establish specific and biologically important preferences for key aspects of their environment. Later he went on to study the vital role of play in the development of cognitive and social skills in species such as cats and monkeys. In the 1980s, he turned his attention to animal ethics and welfare by joining the emerging debate on sentience and pain sensitivity in research animals. Among other contributions, Pat proposed a simple but surprisingly powerful utilitarian model for deciding whether a particular study should be allowed to proceed based on a balance between animal suffering, the quality of the research, and the likelihood of it yielding significant benefits. Notably, the resulting 'decision cube' erred on the side of the animal, only allowing the study to proceed when the quality of the research and certainty of benefit was high, and the animal experienced little or no discomfort or distress. 
In the 1990s, at the behest of the National Trust, Britain's largest owner and operator of stately homes and rural estates, Pat and his postdoc, Elizabeth Bradshaw, conducted the first ever scientific study of what happens to the welfare and physiology of animals, such as red deer, when hunted with packs of hounds. The findings were sufficiently disturbing to prompt the National Trust to ban all deer hunting on its properties, and led ultimately to a decision by Britain's then Labour Government to pass a highly controversial law banning all sport hunting with hounds nationally. Needless to say, many groups claimed that this was a direct attack on a key element of English rural heritage, and Pat unwittingly became the victim of a savage campaign to discredit him and his findings. For somebody as unfailingly polite and considerate as Pat, such personal attacks shocked and upset him quite deeply.

More recently, Pat also became embroiled in the controversy triggered by the hardhitting British documentary, Pedigree Dogs Exposed (2008), that examined the health and welfare problems of purebred dogs. He was invited by the Department of the Environment, Agriculture and Rural Affairs (Defra); The Dogs Trust; and the Kennel Club to lead an independent enquiry into dog breeding practices in the UK. The results were published in 2010 and made a series of sweeping recommendations designed to curb the worst practices of the dog breeding community. He was also the keynote speaker at the Purebred Paradox conference co-organized in Washington, DC, by the HSUS and the University of Pennsylvania's Center for the Interaction of Animals and Society in 2011.

Finally, Pat Bateson was a great lover of cats. He and his wife, Dusha, bred several generations of Russian Blues and Egyptian Maus, and he and Dennis Turner co-edited the authoritative The Domestic Cat: The Biology of Its Behaviour, now in its third edition. Personally, I will always remember Pat as a surpassingly generous, kind, and warm-hearted man with a wonderful sense of humor, a love for the good things in life, and a passion for scientific ideas and speculations. With his passing, the world has lost a great intellect and a staunch champion of animal welfare science.

Paul Patrick Gordon Bateson, born March 31, 1938; died August 1, 2017. 